\title{
A Note from the Editor
}

With this issue, Deidre Sklar leaves Dance Research Journal as Reviews Editor. I want to thank Deidre for her excellent work, her thoughtfulness in selecting books and reviewers, her care in editing, her passion for our field, and her ever delightful correspondence during the years we have worked together. It has been a pleasure and a stimulus to my own work to have had Deidre as a colleague in this enterprise. At the same time, I am happy to welcome our new Reviews Editor, Joellen Meglin, with whom I have worked as a faculty colleague for several years. I know that Joellen will continue the fine work undertaken by Deidre, and by the Reviews Editors before her.

As Deidre departs, she initiates new paths for us. Please note her call, at the start of the "Reviews" section of this issue, for a researchers' dialogue on themes, issues, and methodologies in our field. This "Readers Forum" is not constrained to the reviews alone. Please consider the articles, reports, and any other material published in $D R J$ as subject for debate, discussion, inquiry. Let us not be passive readers! Please address correspondence to the Editor or the Reviews Editor, Dance Research Journal, Dance Program, Franklin \& Marshall College, P.O. Box 3003, Lancaster, PA 17604-3003. We look forward to hearing from you.

Lynn Brooks

Editor 


\section{CONGRESS ON RESEARCH IN DANCE}

Department of Dance, State University of New York College at Brockport,

Brockport, New York 14420 U.S.A.

\section{AVAILABLE PUBLICATIONS}

Postage: $\$ 1.50$ for first volume; $\$ .50$ each additional volume; payable by check to CORD in U.S. dollars.

Special (Stepanov Dance Notation by A. Gorsky, trans. R. J. Wiley)

Journals VIII/1 Fall/Winter '75-'76 (African Dance, Eskimo Dance; Margaret H'Doubler's class; The Sleeping Princess)

15/2 Spring ' 83 (The Savoy; Norton and Margot, Afro-American Social Dance; Disco: Afro-American Vernacular Performance)

20/1 Summer '88 (Poetry and Dance; Cholly Atkins; Netherlands: Seventeenth and Eighteenth Centuries; Afro-American Transformations; Body Composition and Measurement Techniques; Gershwin's Concerto in F)

21/1 Spring '89 (Philadelphia Dancing Assembly; Psychological Tension in Ballet Performance; The Green Table - Sources)

21/2 Fall '89 (Yoruba Recreational Dances; Nutritional Status of Ballet Dancers; Technique and Autonomy in Ballet)

22/1 Spring '90 (Valentine de Saint-Point; Physiologic Profiling of Modern Dancers; Recruitment Patterns in Ballet and Modern Dance)

22/2 Fall '90 (Black Faces, Garlands, and Coconuts; Voices of Young Women Dance Students; The Beseda: Czech National Dance in Iowa)

23/1 Spring '91 (Modes of Inquiry: Approaches to Dance Research; References to Dance in Sacre Rappresentazioni ; Black Philadelphia's Dance Institutions)

23/2 Fall '91 (Changing Values in Cuban Rumba; Effects of Participation in Dance on French Children; Hasta: T. Balasaraswati and her Art)

24/1 Spring '92 (Water Study; The Moore's Pavan: Interview with Lucas Hoving; Havelock Ellis's "The Art of Dancing")

24/2 Fall '92 (Nijinska and the Polish Ballet; What Constitutes a Dance?: Tudor's Dark Elegies; Critical Evaluation in Choreography Class)

25/1 Spring '93 (European Linked Sword Dancing; Schnitzler's The Bridal Veil, Contra Dance in New England)

25/2 Fall '93 (Agon: An Analysis; Qualitative Change in Performance of Korean Dance;John Blacking and Dance Anthropology in the U.K.)

26/1 Spring '94 (Old time Square Dancing, Training Principles for Neuromuscular Facilitation, Personal Style as a Mediator of Engagement in Dance)

26/2 Fall '94 (Katherine Dunham's Southland, East and West in the Work of Michio Ito, Duncan's Dance Theory) 